\title{
Intraspecific competition for food within and between year classes in the deposit-feeding amphipod Monoporeia affinis - the cause of population fluctuations?
}

\author{
Johan Wenngren*, Emil Ólafsson \\ Department of Zoology, Stockholm University, 10691 Stockholm, Sweden
}

\begin{abstract}
We investigated whether intraspecific competition for food and/or other possible densitydependent interactions occurred within and between 2 age classes of the deposit-feeding amphipod Monoporeia affinis. A 2 -factor laboratory experiment was conducted, where juveniles (0+) and adults (1+) were kept in experimental jars for $2 \mathrm{mo}$ at densities of 2000, 4000 and 8000 ind. $\mathrm{m}^{-2}$, which corresponds to natural abundances in the Baltic Sea. The amphipods were fed on a mixture of naturally occurring algae at 3 food levels: zero, medium (representing a diatom spring-bloom) and high (representing a $2 \times$ diatom spring-bloom). The level of food added to the experimental jars determined whether food competition occurred, both within and between the 2 age classes. Growth of juveniles was not density-dependent, at any food level, in the absence of adults, but clearly dependent on presence or absence of fresh algal material. In presence of high adult densities, the growth of juveniles was significantly reduced at food levels that corresponded to a single and twice a diatom springbloom, while such reduction was not found in jars without added algae. Growth of adults was both density- and food-dependent. Juveniles did not affect the survival and growth of adults. As high densities of amphipods in jars without added food affected neither growth nor mortality, we conclude that crowding effects such as predation or directly damaging interference are not important regulating mechanisms. The results indicate that exploitative intraspecific competition for food occurs both between and within year classes, but depends on the resource levels and is likely to be most intense under a regime of low to medium input of phytodetritus. The experiment lends support to the hypothesis that intraspecific competition for food acts as an important process causing fluctuations in the Baltic Sea populations of M. affinis.
\end{abstract}

KEY WORDS: Baltic Sea · Amphipods · Intraspecific food competition · Age classes · Laboratory experiments

\section{INTRODUCTION}

One of the most important tasks in ecology is to understand which factors regulate abundance and distribution of organisms. In terrestrial and marine rocky intertidal habitats, biotic interactions such as competition can play an important role for population regula-

*E-mail: johan.wenngren@zoologi.su.se tion and community structure, for example (Branch 1984, Goldberg \& Barton 1992). However, in marine soft bottom habitats, the role of biotic interactions as a structuring force is not well understood. In marine subtidal (>10 m) areas, soft bottoms with relatively stable environmental conditions dominate the ocean floor. In such areas, it has been suggested that the benthic secondary biomass production is driven by the input of sedimentary organic matter (Graf 1989), and that biomass of macrofauna increases with organic load up to 
the point when its decomposition leads to anoxia (Pearson \& Rosenberg 1978). Such bottoms are typically dominated by deposit feeders that utilise organic matter from the ingested sediment as food (Lopez \& Levinton 1987). In temperate aquatic environments the availability of such food may vary widely through the year, and consequently, resources may be limiting for long periods. Levinton (1972) theorised that benthic deposit-feeding communities are generally limited by food availability and that intense competition for food resources is to be expected. Results from several laboratory and field experiments, where either food supply or animal density has been manipulated, indicate negative relationships between density and growth, and positive relationships between growth and food resources in marine deposit feeders: in mudsnails (Fenchel \& Kofoed 1976, Levinton \& Bianchi 1981, Levinton 1985, Morrisey 1987), in gastropods (Branch \& Branch 1980), in bivalves (Ólafsson 1986, Kamermans et al. 1992), in polychaetes (Wilson 1983) and in amphipods (Jensen \& Kristensen 1990).

Density-dependent growth may have different effects on population dynamics depending on the life history traits of the species in question. Ebenman (1988) theorised that population dynamics of animals with distinct age classes and similar requirements of food resources would be heavily influenced by intraspecific competition. As far as we know, there are no studies from soft bottoms concerning the effects of juveniles on conspecific adult populations. However, from intertidal rocky shores, Underwood (1976) and Fletcher (1988) showed that increases in population densities of juvenile gastropods affected the adults more than the juveniles.

In their review on recruitment limitation in soft bottom habitats, Ólafsson et al. (1994) concluded that soft bottom macrofauna should be, to a large extent, regulated by adult-juvenile post-settlement processes causing direct or delayed juvenile mortality, and not by recruitment limitation (e.g. adult mortality and/or adult fecundity). In species that have distinct year classes, 3 experiments indicate that adults depress the survival and/or growth of juveniles: in polychaetes (Kent \& Day 1983) and in amphipods (Wilson 1989, Hill 1992).

Like in many other marine areas, the macrofaunal community of subtidal $(>10 \mathrm{~m})$ soft bottoms in the Baltic Sea is dominated by deposit-feeding organisms. One of the most abundant and widespread members of this species-poor community is the amphipod Monoporeia affinis (formerly Pontoporeia affinis) (Lindström) (Segerstråle 1957, Ankar \& Elmgren 1976, Andersin \& Sandler 1991). It utilises benthic bacteria (Ankar 1977 , Goedkoop \& Johnson 1994) and settled phytoplankton as food (Lopez \& Elmgren 1989, Aljetlawi et al. 2000, van de Bund et al. 2001), while meiofauna seem not to be important (Ólafsson \& Elmgren 1991). The main period of growth is during the spring diatom bloom and a few months thereafter (Cederwall 1977, Elmgren 1978, Sarvala 1986, Sarvala \& Uitto 1991, Lehtonen \& Andersin 1998). M. affinis is semelparous with a lifecycle lasting from 1 to 4 yr (Leonardsson et al. 1988), and therefore, there are often at least 2 year classes present at the same time.

The abundance of Monoporeia affinis fluctuates interannually, with maximum abundance in March and April, after the release of the new juvenile cohort, followed by a rapid decline in numbers during summer (Cederwall 1977, Karjala \& Lassig 1985, Sarvala 1986, Sarvala \& Uitto 1991). The abundance of M. affinis has also been reported to fluctuate greatly between years in many areas of the Baltic Sea (Andersin et al. 1978, Karjala \& Lassig 1985, Sarvala 1986, Leonardsson 1994, Lehtonen \& Andersin 1998) and in Swedish lakes (Johnson \& Wiederholm 1989, 1990). Sarvala (1986) proposed that the annual fluctuations are due to intraspecific competition for food, resulting in high mortality of juveniles soon after their release in spring. This hypothesis has been supported by field studies in the Baltic Sea (e.g. Sarvala 1986, Lechtonen \& Andersin 1998) and from the Swedish lake Mälaren (Johnson \& Wiederholm 1989), where growth and/or mortality of juvenile $M$. affinis was shown to be density dependent of older age classes. Further, laboratory experiments conducted by Hill (1992) and Goedkoop \& Johnson (1994) indicate that growth in juvenile $M$. affinis depends on the density of adults $(1+)$ and juveniles. However, in neither of these studies was the food level manipulated or estimated, making it difficult to interpret the results and to distinguish between competition for food and other possible crowding effects. Elmgren et al. (2001) found density-dependent growth of both juveniles and adults (1+) of M. affinis, and that adult growth was food-dependent. They concluded that the amphipods were primarily limited by food and not by crowding as such. However, the study suffers from limitations in the experimental design in that they tested the effects of 2 interacting factors in separate independent experiments, i.e. density and food levels. Further, a problem the authors discussed themselves is that in their experiment designed to test for food limitation, the authors added baker's yeast as food, which is questionable, as such food is not found in the natural surroundings.

Here, we report on an experiment where both natural food resources and amphipod densities were manipulated simultaneously to assess the importance of competition within and between 2 year classes of the amphipod Monoporeia affinis. We were particularly interested in the following questions: (1) Do these 
amphipods compete for food? To answer this question we needed to know if there is density-dependent growth and/or mortality with and without natural food resources. If such competition is occurring in the amphipods, we would expect less weight and/or survival at high animal densities in treatments with a medium input of food, but less weight and/or survival differences among animal densities in treatments without added food. Obviously such competition could be both within and between the year classes. (2) Are there crowding effects not related to food competition such as predation and/or directly damaging interference? A strong indication of such crowding effects would be a density-dependent mortality and/or growth in absence of natural food resources.

\section{MATERIALS AND METHODS}

Before the spring phytoplankton bloom on 10 March 1999, sediment was collected with a van Veen bottom grab from a $28 \mathrm{~m}$ deep soft bottom station near the Askö Laboratory field station $\left(58^{\circ} 49^{\prime} \mathrm{N}, 17^{\circ} 34^{\prime} \mathrm{E}\right)$. The $5 \mathrm{~cm}$ organic-rich top layer of the sediment was removed and the remaining sediment was sieved through a $300 \mu \mathrm{m}$ mesh and then stored aerated at $7^{\circ} \mathrm{C}$ in the dark under $10 \mathrm{~cm}$ of seawater. In late April, the sediment was mixed to ensure homogeneity and then poured into $1.5 \mathrm{l}$ plastic jars $\left(100 \mathrm{~cm}^{2}\right)$, creating a $6 \mathrm{~cm}$ deep sediment layer (Fig. 1). The jars were connected to a supply of cooled natural brackish water from $16 \mathrm{~m}$ depth, sieved through a sand filter and a $20 \mu \mathrm{m}$ mesh with a flow rate of $1.5 \mathrm{l} \mathrm{h}^{-1}$. The outlet from each jar was covered with a $200 \mu \mathrm{m}$ mesh to prevent the amphipods from escaping. Outflow water from the jars

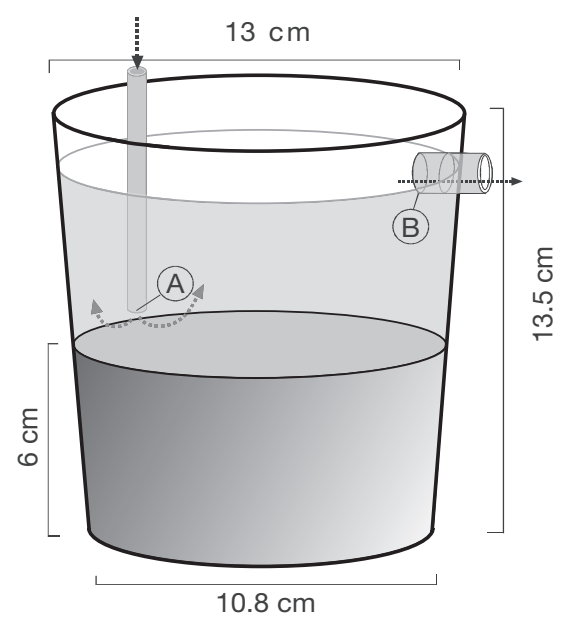

Fig. 1. Schematic presentation of an experimental microcosm. (A) $20 \mu \mathrm{m}$ mesh, (B) $200 \mu \mathrm{m}$ mesh. Arrows show path of brackish water flow, hatched bottom area represents sediment was not recycled. Experiments were conducted in a dark room, where water temperature and salinity were kept close to field levels at 5 to $8^{\circ} \mathrm{C}$ and 5.9 to $6.3 \%$ during the period.

Monoporeia affinis were collected with a benthic sledge (Blomqvist \& Lundgren 1996) at the end of April from the same station as the sediment and sorted into batches of 10 by means of a small nylon net. One hundred individuals of both juveniles $(0+)$ and adults (1+) were randomly sorted into batches of 20 and preserved in $4 \%$ formaldehyde solution to obtain initial mean length in both age classes and initial mean dry weight in adults. Length was measured from the base of the first antenna to the last abdominal segment with the aid of camera lucida using a light microscope. Adults were rinsed in freshwater, dried at $80^{\circ} \mathrm{C}$ to a constant weight and then lumped together in numbers of 20 to obtain the initial mean dry weight for the year class. Batches of juveniles (age 0+, mean length $=1.76 \mathrm{~mm}$, $\mathrm{SE}= \pm 0.11, \mathrm{n}=5$ with 20 ind. each) and adults (age $1+$, mean length $=6.38 \mathrm{~mm}, \mathrm{SE}= \pm 0.28$, mean dry weight $=0.975 \mathrm{mg}, \mathrm{SE}= \pm 0.096, \mathrm{n}=5$ with 20 ind. each) were randomly selected and placed into the jars to make up the required number of amphipods.

A total of 135 jars were used to permit 27 treatments with 5 replicates each, arranged in a randomised block design. The main experimental set-up consisted of 4 sub-units: (1) effects of adults on juveniles; (2) effects within juveniles; (3) effects within adults; and (4) effects of juveniles on adults. The low-density treatments were 20 juveniles or 20 adults (2000 ind. $\mathrm{m}^{-2}$ ). Juveniles or adults were added in numbers of 20 or 60 in 9 combinations (Table 1 ) resulting in total densities of 20,40 or 80 amphipods $\left(2000,4000\right.$ and 8000 ind. $\mathrm{m}^{-2}$ respectively), which corresponds to naturally occurring abundances of Monoporeia affinis in the Baltic Sea. For example, in the Askö area, abundances can reach up to 2000 adults and 1500 to 7000 juveniles $\mathrm{m}^{-2}$ in March to April (Ankar \& Elmgren 1976, Cederwall 1977); in the Gulf of Finland, densities of sub-adults (ages $1+$ and 2+) and juveniles can reach more than 6000 and 10000 ind. $\mathrm{m}^{-2}$ respectively (Sarvala \& Uitto 1991); and in the Bothnian Sea, Leonardsson (1994) recorded up to 10000 ind. $\mathrm{m}^{-2}$ (ages $1+$ and $2+$ ).

The amphipods were exposed to 3 different levels of food addition (zero, medium and high). At medium and high food levels, amphipods were fed on a concentrated mixture of the diatoms Nitzschia closterium (Ehrenberg) W. Smith (60\%), Skeletonema costatum (Greville) Cleve (30\%) and other algae $(10 \%)$. The diatom strains were isolated from the study area in March 1999. The algae were cultured in an $\mathrm{f} / 2+24 \% \mathrm{Si}$ medium (described by Guillard 1975) at a temperature of $15^{\circ} \mathrm{C}$, salinity of $15 \%$ and $12: 12 \mathrm{~h}$ light:dark regime. Food was added 13 times, approximately every third 
Table 1. Experimental set-up to investigate the effects of enhanced densities of juveniles and adults on the mortality and growth of juvenile and adult Monoporeia affinis at 3 food levels $\left(\mathrm{gC} \mathrm{m}^{-2}\right)$. Each treatment consisted of 5 replicates

\begin{tabular}{|c|c|c|c|c|}
\hline Treatment & $\begin{array}{c}\text { Juvenile } \\
\text { density }\end{array}$ & $\begin{array}{c}\text { Adult } \\
\text { density }\end{array}$ & $\begin{array}{c}\text { Total } \\
\text { density }\end{array}$ & $\begin{array}{l}\text { Food } \\
\text { level }\end{array}$ \\
\hline 1 & 20 & 0 & 20 & 0 \\
\hline 2 & 20 & 0 & 20 & 6.1 \\
\hline 3 & 20 & 0 & 20 & 12.2 \\
\hline 4 & 40 & 0 & 40 & 0 \\
\hline 5 & 40 & 0 & 40 & 6.1 \\
\hline 6 & 40 & 0 & 40 & 12.2 \\
\hline 7 & 80 & 0 & 80 & 0 \\
\hline 8 & 80 & 0 & 80 & 6.1 \\
\hline 9 & 80 & 0 & 80 & 12.2 \\
\hline 10 & 20 & 20 & 40 & 0 \\
\hline 11 & 20 & 20 & 40 & 6.1 \\
\hline 12 & 20 & 20 & 40 & 12.2 \\
\hline 13 & 20 & 60 & 80 & 0 \\
\hline 14 & 20 & 60 & 80 & 6.1 \\
\hline 15 & 20 & 60 & 80 & 12.2 \\
\hline 16 & 0 & 20 & 20 & 0 \\
\hline 17 & 0 & 20 & 20 & 6.1 \\
\hline 18 & 0 & 20 & 20 & 12.2 \\
\hline 19 & 0 & 40 & 40 & 0 \\
\hline 20 & 0 & 40 & 40 & 6.1 \\
\hline 21 & 0 & 40 & 40 & 12.2 \\
\hline 22 & 0 & 80 & 80 & 0 \\
\hline 23 & 0 & 80 & 80 & 6.1 \\
\hline 24 & 0 & 80 & 80 & 12.2 \\
\hline 25 & 60 & 20 & 80 & 0 \\
\hline 26 & 60 & 20 & 80 & 6.1 \\
\hline 27 & 60 & 20 & 80 & 12.2 \\
\hline
\end{tabular}

day, during the first $35 \mathrm{~d}$ of the $64 \mathrm{~d}$ long experiment by carefully injecting 10 or $20 \mathrm{ml}$ (in medium and high food level respectively) of algae solution (salinity of $15 \%$ ) to the water column. To facilitate settlement of the algal mixture, the water flow was shut off for $5 \mathrm{~h}$ during the feeding procedure. The carbon content of the added algae (mean $=13 \%$ of dry weight) was estimated at each feeding event by sieving $25 \mathrm{ml}$ of algal mixture through a $20 \mu \mathrm{m}$ glassfiber filter and drying at $80^{\circ} \mathrm{C}$ until constant weight, followed by carbon analysis in a CHN analyser (CHN-900, 600-800-300, Leco Corporation). Dry weight of algal carbon added to each microcosm during the experiment was $61 \mathrm{mg} C$ (equals $6.1 \mathrm{~g} \mathrm{C} \mathrm{m}^{-2}$ ) in treatments with the medium food level and $122 \mathrm{mgC}$ (equals $12.2 \mathrm{~g} \mathrm{C} \mathrm{m}^{-2}$ ) in treatments with the high food level, which is in the range of reported field values in the Baltic Sea. Carbon weight of settled spring bloom material has in the Askö area been reported to reach a mean of $4.9 \mathrm{gC} \mathrm{m}^{-2}$ (Larson et al. 1986), while in the Kiel Bight, SW Baltic Sea, Graf et al. (1982) recorded $11.5 \mathrm{~g} \mathrm{C} \mathrm{m}^{-2}$. The highest food level in our experiment, $12.2 \mathrm{~g} \mathrm{C} \mathrm{m}^{-2}$, corresponds well with the patches of accumulated spring bloom material that can be found in the field.

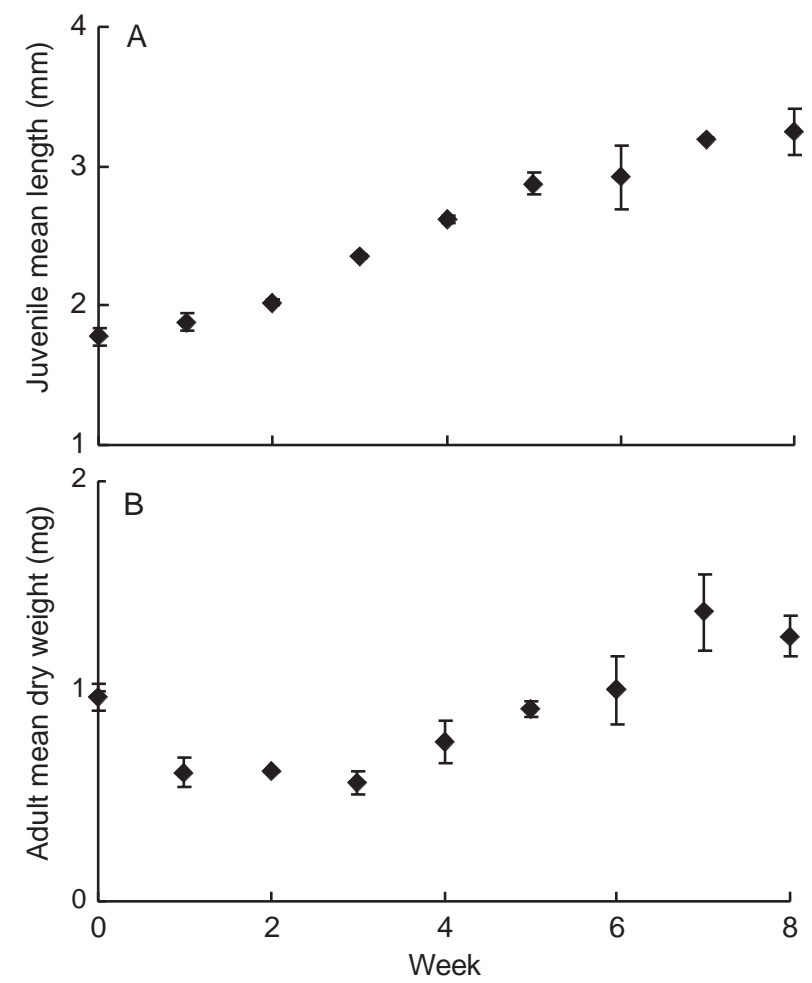

Fig. 2. Monoporeia affinis. Weekly (A) juvenile length and (B) adult dry weight (mean \pm SE) at medium food level and 20 individuals

The point of time to terminate the experiment was based on a parallel experiment. A total of 48 jars were used, each containing either 20 juveniles or 20 adults. Both age classes were fed with medium food supply in the same way and at the same time as in the main experiment. Each week, 2 jars of both juveniles and adults were randomly removed and amphipods were analysed for length and weight. The main experiment was terminated when both juveniles and adults showed significant positive growth (Fig. 2). Adults showed a clear positive growth in weight but not for length. Therefore, for the main experiment, we chose to analyse adult weight only. Juveniles showed a clear positive growth both in length and weight; however, due to the high risk of errors when weighing very few juveniles, we chose to analyse juvenile length only.

At the end of the experiment, after $64 \mathrm{~d}$, the amphipods were extracted from the sediment, living amphipods counted and preserved in $4 \%$ formaldehyde solution. When numbers permitted, 10 juveniles were randomly chosen for length analysis, and all adults from each jar were lumped together to obtain the mean dry weight (methods of measuring length and dry weight were the same as described earlier).

For each of the 4 sub-units, a 2-factor analysis of variance (2-way ANOVA) was used to separate the 
effects of density and food level and to test for an interaction. When interactions were found, a 1-way ANOVA was performed on 1 factor separately at each level of the other factor, followed by an a posteriori Tukey's test using $95 \%$ confidence limits. When no interactions were found, multiple comparisons, using the Tukey's test with the $95 \%$ confidence limits, were done on each significant factor (Underwood 1997). Mortalities (proportions) were arcsine-transformed, and growth data (length and weight) were $\log _{10}$-transformed (Sokal \& Rohlf 1995) to avoid heterogeneity of variance (Cochran's $C$-test, $\mathrm{p}<0.05$ ).

\section{RESULTS}

\section{Effects of adults on juveniles}

Mean mortality of juveniles ranged between 12 and $76 \%$ and was not significantly affected by the presence of adults. However, there was significantly higher mortality in treatments without food addition com-
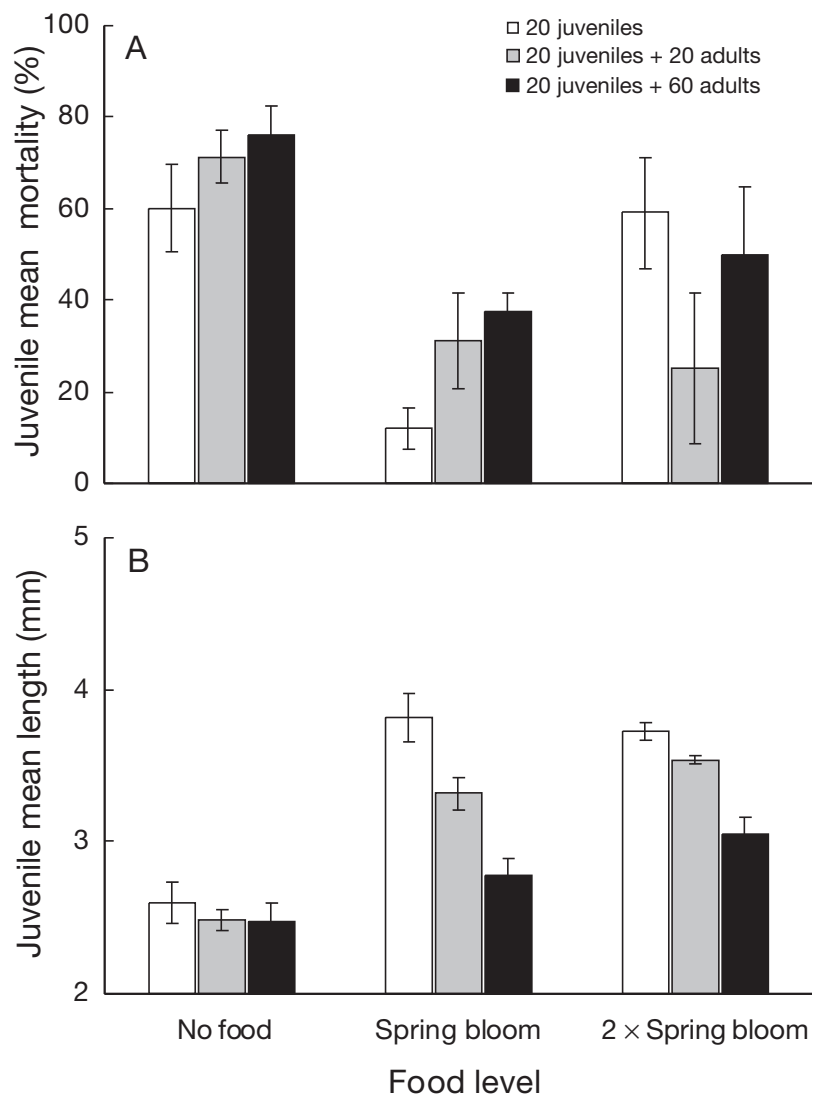

Fig. 3. Monoporeia affinis juveniles. (A) Mortality and (B) length (mean $\pm \mathrm{SE}$ ) at 3 adult densities and at 3 food levels: (1) zero $\left(0 \mathrm{~g} \mathrm{C} \mathrm{m}^{-2}\right)$, (2) medium $\left(6.1 \mathrm{~g} \mathrm{C} \mathrm{m}^{-2}\right)$ and (3) high (12.2 $\left.\mathrm{g} \mathrm{C} \mathrm{m}^{-2}\right)$
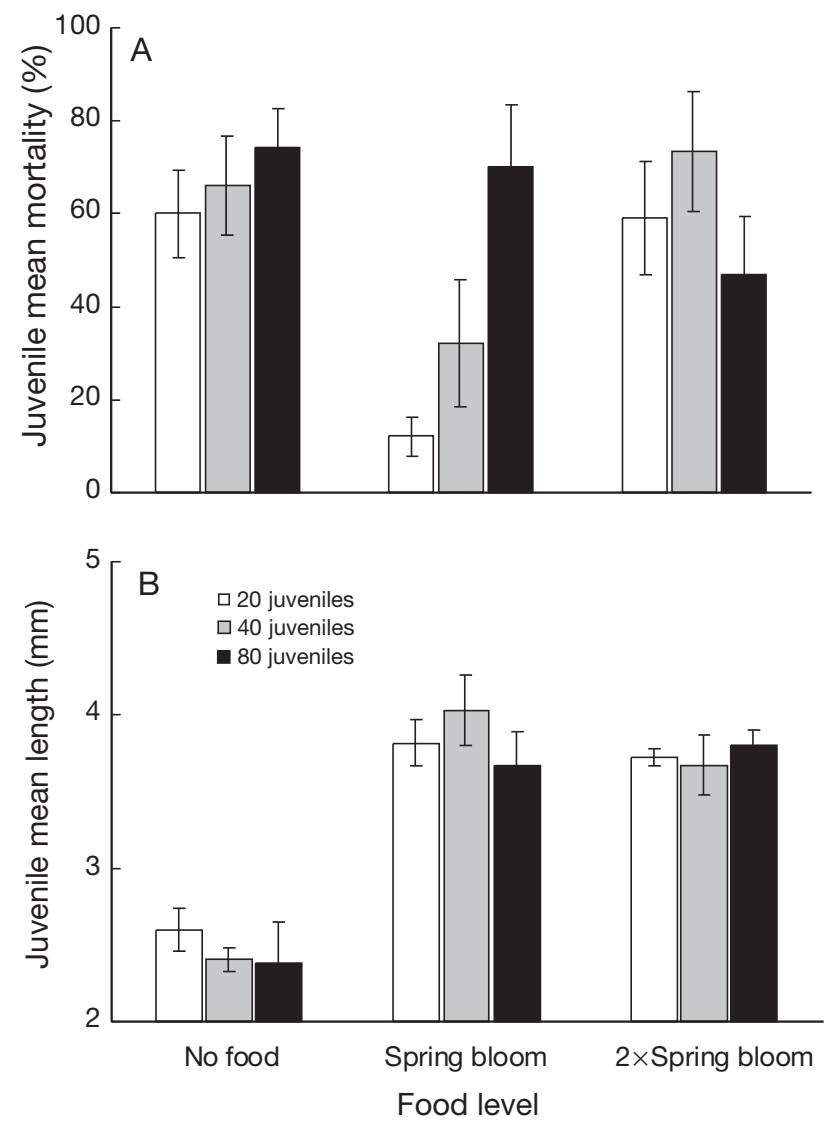

Fig. 4. Monoporeia affinis juveniles. (A) Mortality and (B) length (mean $\pm \mathrm{SE}$ ) at 3 juvenile densities and at 3 food levels (see Fig. 3)

pared to those of medium and high food levels (2-way ANOVA, Density: $p>0.05$, Food level: $p<0.01$, Density $\times$ Food level: $p>0.05$, Tukey's test, $p<0.05$; Fig. 3A). The growth of juveniles was density-dependent so that their length was smaller at the highest adult density at medium and high food levels (2-way ANOVA, Density: $p<0.001$, Food level: $p<0.001$, Density $\times$ Food level: $\mathrm{p}<0.05,1$-way ANOVA: $\mathrm{p}<0.001$, Tukey's test: $p<0.05$; Fig. 3B), but the presence of adults did not affect growth in juveniles given no food (1-way ANOVA: $p>0.05)$.

\section{Effects within juveniles}

Mean juvenile mortality ranged from 12 to $74 \%$ and increased significantly at the highest juvenile densities at the medium food level (2-way ANOVA, Density: $p>0.05$, Food level: $p<0.01$, Density $\times$ Food level: $\mathrm{p}<0.05,1$-way ANOVA: $\mathrm{p}<0.01$, Tukey's test, $\mathrm{p}<0.05$; Fig. 4A), while there were no density effects on juvenile mortality at the zero and high food levels (1-way 
ANOVA: $p>0.05$ ). The growth of juveniles was not density-dependent; however, juvenile length was greater in treatments where food had been added (2-way ANOVA, Density: $\mathrm{p}>0.05$, Food level: $\mathrm{p}<$ 0.001 , Density $\times$ Food level: $\mathrm{p}>0.05$, Tukey's test, $\mathrm{p}<$ 0.05; Fig. 4B).

\section{Effects within adults}

Mean mortality in adults was much lower than in juveniles, ranging from 6.5 to $21.5 \%$. There were no significant differences in adult mortality among the treatments and no significant interaction between density and food level (2-way ANOVA, Density: $p>0.05$, Food level: $\mathrm{p}>0.05$, Density $\times$ Food level: $\mathrm{p}>0.05$; Fig. 5A). Growth in adults was density-dependent at the highest food level so that weight was significantly smaller at the high-density treatment (2-way ANOVA, Density: $p>0.05$, Food level: $p<0.01$, Density $\times$ Food level: $\mathrm{p}<0.05,1$-way ANOVA: $\mathrm{p}<0.05$, Tukey's test,
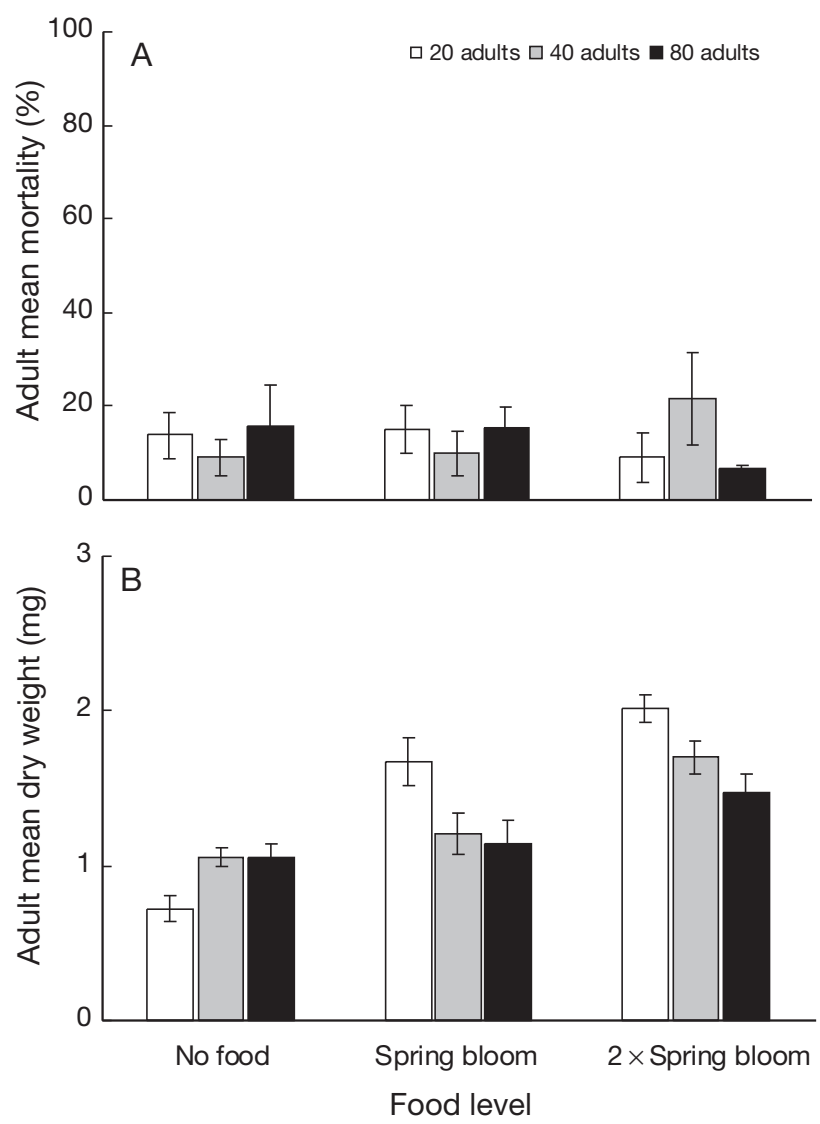

Fig. 5. Monoporeia affinis adults. (A) Mortality and (B) dry weight (mean $\pm \mathrm{SE}$ ) at 3 adult densities and at 3 food levels (see Fig. 3)
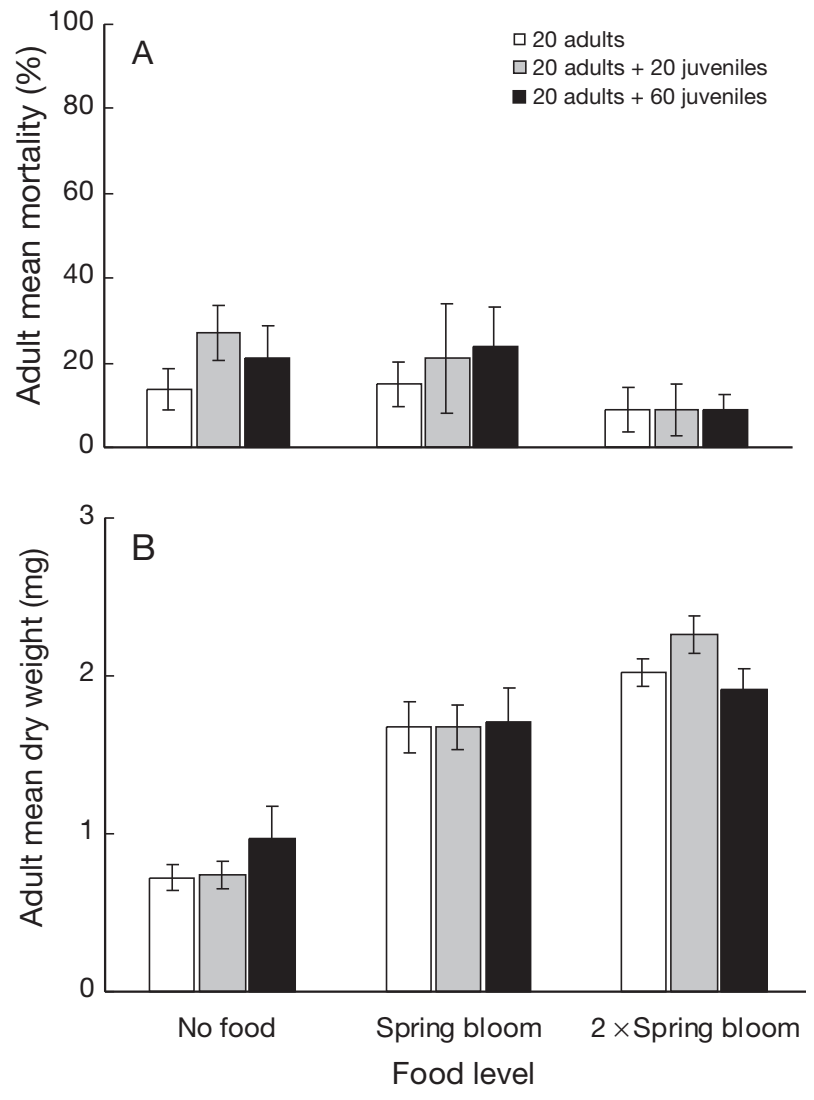

Fig. 6. Monoporeia affinis adults. (A) Mortality and (B) dry weight (mean $\pm \mathrm{SE}$ ) at 3 juvenile densities and at 3 food levels (see Fig. 3)

$p<0.05$; Fig. 5B). There were no significant density effects at the zero and medium food levels (1-way ANOVA, $\mathrm{p}>0.05$ ).

\section{Effects of juveniles on adults}

Juveniles did not have significant density effects on adults, while both survival and growth responded positively to food addition (2-way ANOVA, Density: $\mathrm{p}>0.05$, Food level (mortality): $p<0.05$, Food level (growth): $\mathrm{p}<0.001$, Density $\times$ Food level: $\mathrm{p}>0.05$, Tukey's test, $\mathrm{p}<0.05$; Fig. 6).

\section{DISCUSSION}

The results clearly show that intraspecific competition was occurring in Monoporeia affinis in the experimental jars, both within and between year classes. In the presence of added food resources, adult growth was density-dependent and high densities of adults had ob- 
vious negative effects on growth of juveniles. As we did not see such effects in the absence of natural food resources, i.e. no significant growth and mortality differences were detected among densities at the lowest food level, exploitative and/or interference competition for food seems to be the most natural explanation. However, in juveniles, a density-dependent trend for mortality was detected at the lowest food level both with and in the absence of adults, which may indicate a small contribution of directly damaging crowding effects. The data therefore cannot exclude the possibility that adults may directly harm juveniles, as suggested by Hill (1992), who found greater mortality in juveniles at high adult densities. Our data showed that juveniles under normal food regimes and high density of adults were only marginally larger than juveniles without food. It is therefore plausible that these juveniles would suffer much higher mortality than those that did not compete for food, given longer experimental time (see Fig. 3), suggesting that higher mortality in the presence of adults in Hill (1992) was more likely an effect of competition for food than of direct damage or predation.

In our experiment, the mortality in treatments with only juveniles was density-dependent at the medium food level. This pattern was unexpected, because juvenile growth was not density-dependent and adults did not have any significant density effects on juvenile mortality (see Fig. 4). The only plausible explanation we have for this density-dependent pattern is that competition for oxygenated space occurred. After $50 \mathrm{~d}$, the presence of patchy black sediment was detected in jars with only juveniles at medium respectively high food levels, suggesting occurrence of oxygen deficiency due to food decomposition. Monoporeia affinis has been classified as very sensitive to low oxygen concentrations (Johansson 1997) and has been shown to die in pulses of hypoxia (Modig \& Ólafsson 1998).

Our intention was to imitate field conditions as far as possible. However, negative abiotic influences (e.g. oxygen deficiency) and/or intraspecific interactions may be stronger in jars than in the field, as amphipods are not able to escape. Monoporeia affinis swim actively at night (Lindström \& Lindström 1980) and swimming activity may increase at higher densities (Lindström \& Fortelius 1990, 2001). Juveniles of another deposit-feeding amphipod, Corophium volutator (Pallas), have been shown to migrate when density of adults is high (Wilson 1989). Hence, it is possible that juveniles and adults in the field do not share the habitat to such an extent as in this experiment. Unfortunately, there are no data available on spatial distribution of both juvenile and adult $M$. affinis after the settling of phytodetritus in spring and summer.

Ideas about the role of intraspecific competition in the population dynamics of Monoporeia affinis are based largely upon field surveys. Results from such field surveys in the Baltic Sea indicate that growth in older age classes of $M$. affinis (1+ or older) are densitydependent (Sarvala 1986, Leonardsson 1994, Lehtonen \& Andersin 1998). Leonardsson (1994) suggested that the main impact comes from competition for food within age classes, as similar sizes of $M$. affinis are likely to use the same size fraction of the food resource. Our results certainly show that food competition affecting growth can occur within adult age classes. However, the adult $(1+$ and older) mortality of $M$. affinis seems not to be density-dependent at common field densities (Leonardsson 1994, Lehtonen \& Andersin 1998) and we found neither food nor density-dependent mortality within the adults in our study. Therefore, if competition within adult age classes of $M$. affinis is an important population-regulating factor, it is likely that a growth-related parameter must be involved, such as fecundity and/or delayed maturity. Size and fecundity are positively correlated in M. affinis (Cederwall 1977, Lehtonen \& Andersin 1998), and the life cycle length seems to be determined by the time needed to reach a certain minimum size (Leonardsson et al. 1988).

The inter-annual abundance fluctuations reported for several populations of Monoporeia affinis in the Baltic Sea (Andersin et al. 1978, Karjala \& Lassig 1985, Sarvala 1986, Leonardsson 1994, Lehtonen \& Andersin 1998) indicate unstable population dynamics. Ebenman $(1987,1988)$ showed, based on a single-species model with distinct age structure, that dynamics of populations generally are unstable when competition is stronger between age classes than within. Further, if competition affects fecundity, population dynamics should be unstable if juveniles contribute to this competition (Ebenman 1988). However, competition between juvenile and adult affecting the adults seems to be of minor importance at natural field densities. In our experiment, there were no indications of juveniles affecting the adults negatively at tested densities. Even though juvenile amphipods seem to have higher ingestion rates per unit biomass compared to that of adults (Dermott \& Corning 1988), the summed metabolism difference between the experimental populations of juveniles and adults at the start of the experiment may be the most natural explanation, i.e. juveniles that have only approximately $1 / 48$ of the adult's weight (see length-weight relationships in Ankar \& Elmgren 1976), were at tested population densities unable to reduce food resources sufficiently to cause weight reduction in adults.

Ólafsson et al. (1994) argued that in general, the relative importance of recruitment limitation (e.g. adult mortality and/or adult fecundity) in shaping temporal and spatial patterns of abundances and community structures in soft bottom macrofauna might be small 
compared to that of adult-juvenile post-settlement interactions (e.g. juvenile mortality). Results from field surveys conducted by Sarvala (1986) and Lehtonen \& Andersin (1998) indicate that both growth and mortality in juvenile Monoporeia affinis are dependent on the density of adults. In addition, Hill (1992) showed similar results in her laboratory study, and Elmgren et al. (2001) found evidence for food competition in adults (1+) when using baker's yeast as source. Along with our results, that growth of juveniles was densitydependent of adults, but only in the presence of added food; there exists a body of evidence that give strong support to the hypothesis that intraspecific competition for food between older age classes and juveniles acts as an important process causing abundance changes in Baltic Sea populations of $M$. affinis. Further, we demonstrated for the first time that asymmetric competition (juveniles' effects on adults) is unlikely to be important. As we used a 2-factor experimental design, we were able to separate the effects of density and food level. We can therefore conclude that the competitive mechanisms in $M$. affinis are primarily exploitative and/or interference competition for food.

Acknowledgements. We would like to thank the staff at Stockholm Marine Research Centre and Askö Laboratory for assistance in the field and its director B. Ganning for providing accommodation, boats and laboratory facilities, J. Kotta, B. Naeslund and C. Rosén for help with field and laboratory work, L. Kautsky for taxonomic identifications of diatoms, and K. Leonardsson, S. Nylin and 3 referees, R. Elmgren and 2 anonymous ones, who gave valuable comments on earlier versions of the manuscript.

\section{LITERATURE CITED}

Aljetlawi AA, Albertsson J, Leonardsson K (2000) Effect of food and sediment pre-treatment in experiments with a deposit-feeding amphipod, Monoporeia affinis. J Exp Mar Biol Ecol 249:263-280

Andersin AB, Sandler H (1991) Macrobenthic fauna and oxygen deficiency in the Gulf of Finland. Memo Soc Fauna Flora Fenn 67:3-10

Andersin AB, Lassig J, Parkkonen L, Sandler H (1978) Longterm fluctuations of the soft bottom macrofauna in the deep areas of the Gulf of Bothnia 1954-1974; with special reference to Pontoporeia affinis Lindström (Amphipoda). Finn Mar Res 244:137-144

Ankar S (1977) The soft bottom ecosystem of the northern Baltic proper with special reference to the macrofauna. Contributions Askö Lab, Univ Stockholm 19:1-62

Ankar S, Elmgren R (1976) The benthic macro- and meiofauna of the Askö Landsort area: a stratified random sampling survey. Contributions Askö Lab, Univ Stockholm 11: $1-115$

Blomqvist S, Lundgren L (1996) A benthic sled for sampling soft bottoms. Helgol Wiss Meeresunters 50:453-456

Branch GM (1984) Competition between marine organisms: ecological and evolutionary implications. Oceanogr Mar Biol Annu Rev 22:429-593
Branch GM, Branch ML (1980) Competition in Bembicium auratum (Gastropoda) and its effect on microalgal standing stock in mangrove muds. Oecologia 46:106-114

Cederwall H (1977) Annual macrofauna production of a soft bottom in the northern Baltic proper. In: Keegan BF, Ceidigh, PO, Boaden PJS (eds) Biology of benthic organisms. Pergamon Press, Oxford, p 155-164

Dermott RM, Corning K (1988) Seasonal ingestion rates of Pontoporeia hoyi (Amphipoda) in Lake Ontario. Can J Fish Aquat Sci 11:1886-1895

Ebenman B (1987) Niche differences between age classes and intraspecific competition in age-structure populations. J Theor Biol 124:25-33

Ebenman B (1988) Competition between age classes and population dynamics. J Theor Biol 131:389-400

Elmgren R (1978) Structure and dynamics of Baltic benthos communities, with particular reference to the relationship between macro- and meiofauna. Kiel Meeresforsch 4:1-22

Elmgren R, Ejdung G, Ankar S (2001) Intraspecific food competition in the deposit-feeding amphipod Monoporeia affinis (Lindström) - a laboratory study. Mar Ecol Prog Ser 210:185-193

Fenchel T, Kofoed LH (1976) Evidence for exploitative interspecific competition in mud snails (Hydrobiidae). Oikos 27:367-376

Fletcher WJ (1988) Intraspecific interactions between adults and juveniles of the subtidal limpet Patelloida mufria. Oecologia 75:272-277

Goedkoop W, Johnson RK (1994) Exploitation of sediment bacterial carbon by juveniles of the amphipod Monoporeia affinis. Freshw Biol 32:553-563

Goldberg DE, Barton AM (1992) Patterns and consequences of interspecific competition in natural communities-a review of field experiments with plants. Am Nat 139: 771-801

Graf G (1989) Benthic-pelagic coupling in deep-sea benthic community. Nature 341:437-439

Graf G, Bengtsson W, Diesner U, Schulz R, Theede H (1982) Benthic response to sedimentation of a spring phytoplankton bloom: process and budget. Mar Biol 67:201-208

Guillard RRL (1975) Culture of phytoplankton for feeding marine invertebrates. In: Smith WL, Chanley MH (eds) Culture of marine invertebrate animals. Plenum Press, New York, p 29-60

Hill C (1992) Interactions between year classes in the benthic amphipod Monoporeia affinis: effects on juvenile survival and growth. Oecologia 91:157-162

Jensen KT, Kristensen LD (1990) A field experiment on competition between Corophium volutator (Pallas) and Corophium arenarium Crawford (Crustacea: Amphipoda): effects on survival, reproduction and recruitment. J Exp Mar Biol Ecol 137:1-24

Johansson B (1997) Tolerance of the deposit-feeding Baltic amphipods Monoporeia affinis and Pontoporeia femorata to oxygen deficiency. Mar Ecol Prog Ser 151:135-141

Johnson RK, Wiederholm T (1989) Long-term growth oscillations of Pontoporeia affinis Lindström (Crustacea: Amphipoda) in Lake Mälaren. Hydrobiologia 175:183-194

Johnson RK, Wiederholm T (1990) Long-term studies of profundal zoomacrobenthos in Sweden's great lakes: implications of biotic interactions. Ann Zool Fenn 27:291-295

Kamermans P, van der Veer HW, Karczmarski L, Doeglas GW (1992) Competition in deposit- and suspension-feeding bivalves: experiments in controlled outdoor environments. J Exp Mar Biol Ecol 162:113-135

Karjala L, Lassig J (1985) Studies on the benthic macrofauna in the Tvärminne area, Gulf of Finland: 1964-1967 and 
1973-1976. Hydrobiol Res Acad Sci Estonian SSr 15: $169-181$

Kent AC, Day RW (1983) Population dynamics of an infaunal polychaete: the effect of predators and adult-recruit interaction. J Exp Mar Biol Ecol 73:185-203

Larsson U, Hobro R, Wulff F (1986) Dynamics of a phytoplankton spring bloom in a coastal area of the northern Baltic proper. Contributions Askö Lab Univ Stockholm 30:1-32

Lehtonen KK, Andersin AB (1998) Population dynamics, response to sedimentation and the role in benthic metabolism of the amphipod Monoporeia affinis in an open-sea area of the northern Baltic Sea. Mar Ecol Prog Ser 168: $71-85$

Leonardsson K (1994) Multiple density dependence in two sub-populations of the amphipod Monoporeia affinis: a potential for alternative equilibria. Oecologia 97:26-34

Leonardsson K, Sörlin T, Samberg H (1988) Does Pontoporeia affinis (Amphipoda) optimize age at reproduction in the Gulf of Bothnia? Oikos 52:328-336

Levinton JS (1972) Stability and trophic structure in depositfeeding and suspension-feeding communities. Am Nat 106:472-486

Levinton JS (1985) Complex interactions of a deposit feeder with its resources: roles of density, a competitor, and detrital addition in the growth and survival of the mudsnail Hydrobia totteni. Mar Ecol Prog Ser 22:31-40

Levinton JS, Bianchi TS (1981) Nutrition and food limitation of deposit-feeders. I. The role of microbes in the growth of mud snails (Hydrobiidae). J Mar Res 39:531-545

Lindström M, Fortelius W (1990) Some factors affecting the horizontal migration of Pontoporeia affinis (Crustacea, Amphipoda) in laboratory conditions. Ann Zool Fenn 27: 309-312

Lindström M, Fortelius W (2001) Swimming behaviour in Monoporeia affinis (Crustacea: Amphipoda) - dependence on temperature and population abundance. J Exp Mar Biol Ecol 256:73-83

Lindström M, Lindström A (1980) Swimming activity of Pontoporeia affinis (Crustacea, Amphipoda) - seasonal variations and usefulness for environmental studies. Ann Zool Fenn 17:213-220

Lopez G, Elmgren R (1989) Feeding depths and organic absorbtion for the deposit-feeding amphipods Pontoporeia affinis and P. femorata. Limnol Oceanogr 34:982-991

Lopez G, Levinton JS (1987) Ecology of deposit-feeding animals in marine sediments. Q Rev Biol 62:235-260

Modig H, Ólafsson E (1998) Responses of Baltic benthic inver-

Editorial responsibility: Otto Kinne (Editor),

Oldendorf/Luhe, Germany tebrates to hypoxic events. J Exp Mar Biol Ecol 229: 133-148

Morrisey DJ (1987) Effect of population density and presence of a potential competitor on the growth rate of the mud snail Hydrobia ulvae (Pennant). J Exp Mar Biol Ecol 108: 275-295

Ólafsson E, Elmgren R (1991) Effects of disturbance by benthic amphipods Monoporeia affinis on meiobenthic community structure: a laboratory approach. Mar Ecol Prog Ser 74:99-107

Ólafsson EB (1986) Density dependence in suspensionfeeding and deposit-feeding populations of the bivalve Macoma balthica: a field experiment. J Anim Ecol 55: $517-526$

Ólafsson EB, Peterson CH, Ambrose WG Jr (1994) Does recruitment limitation structure populations and communities of macro-invertebrates in marine soft-sediments: the relative significance of pre- and post-settlement processes. Oceanogr Mar Biol Annu Rev 32:65-109

Pearson TH, Rosenberg R (1989) Macrobenthic succession in relation to organic enrichment and pollution of the marine environment. Oceanogr Mar Biol Annu Rev 16:229-311

Sarvala J (1986) Interannual variation of growth and recruitment in Pontoporeia affinis (Lindström) (Crustacea: Amphipoda) in relation to abundance fluctuations. J Exp Mar Biol Ecol 101:41-60

Sarvala J, Uitto A (1991) Production of the benthic amphipod Pontoporeia affinis and P. femorata in a Baltic archipelago. Ophelia 34:71-90

Segerstråle SG (1957) Baltic Sea. Geological Society of America, Memoir 67:751

Sokal RR, Rohlf FJ (1995) Biometry, 3rd edn. WH Freeman, San Francisco

Underwood AJ (1976) Food competition between age-classes in intertidal neritacean Nerita atramentosa Reeve (Gastropoda Prosobranchia). J Exp Mar Biol Ecol 23:145-154

Underwood AJ (1997) Experiments in ecology: their logical design and interpretation using analysis of variance. Cambridge University Press, Cambridge

van de Bund WJ, Ólafsson E, Modig H, Elmgren R (2001) Effects of the coexisting amphipods Monoporeia affinis and Pontoporeia femorata on the fate of a simulated spring diatom bloom. Mar Ecol Prog Ser 212:107-115

Wilson WH Jr (1983) The role of density dependence in a marine infaunal community. Ecology 64:295-306

Wilson WH Jr (1989) Predation and the mediation of intraspecific competition in an infaunal community in the Bay of Fundy. J Exp Mar Biol Ecol 132:221-245

Submitted: January 14, 2002; Accepted: April 15, 2002

Proofs received from author(s): August 23, 2002 